\title{
SOME MACROFUNGI FROM PHULCHOWKI AREA OF KATHMANDU VALLEY, NEPAL
}

\author{
Sanjay Kumar Jha and N.N. Tripathi* \\ Bacteriology and Natural Pesticide Laboratory \\ Department of Botany, DDU Gorakhpur University, Gorakhpur-273009, India \\ *E-mail: nijendratripathi@rediffmail.com
}

\begin{abstract}
During present study, a survey was made from Godavari to Phulchowki, Kathmandu valley up to the height of $2250 \mathrm{~m}$. in order to collect macrofungi with special reference to habit, habitat, substrate and ethnobotanical information. The species were brought to laboratory and identified through morphological and microscopic examination. Out of 45 macrofungi species collected, 20 species belonging to 13 families were identified. The major species were Agaricus silvicola, Amanita caesarea, Bovista plumbea, Clavulina cristata, Clavulinopsis fusiformis etc. The detailed measurement of pileus and stipes, colour of pileus, gills and stipes, cap profiles, stem profiles, spore structure were done.
\end{abstract}

Key words: $\quad$ Macrofungi, medicinal fungi, Phulchowki.

\section{INTRODUCTION}

The typical position of Nepal, lying in the North of Indian subcontinent and in the central part of the Himalayan range, shows an assemblage of diversity in phytogeographical factors. It makes the country a zone of immense biodiversity. Adhikari (2000b) reported nine genera of Ascomycotina and twenty-eight genera of Basidiomycotina from Maipokhari, East Nepal. Further, Adhikari (2001) reported 11 wild mushroom species from Kathmandu valley. Adhikari (2004) studied the mushroom poisoning and its state in Nepal. The major report of Christensen et al. (2008) is available which recorded 228 species of wild fungi from Nepal.

The most common type of macrofungi is umbrella shaped while other species are in the form of pliable cups, round like golf balls. Besides, they are in the shape of small clubs, coral and human ear like. Macrofungi may be edible, nonedible, medicinal and poisonous too. Many kinds of macrofungi are not edible, but also possess tonic and medicinal qualities (Chang and Miles 2004). Macrofungi are heterotrophic, saprophytes and utilize lignocellulosic wastes. Mushroom is a macrofungi with a distinctive fruiting body, which can be either epigeous or hypogenous and large enough to be seen with naked eye and to be picked up by hand. The available literature shows limited and scanty information on macrofungi species of Phulchowki area (situated on the south-east corner of the Kathmandu valley). Therefore, present study was undertaken to collect information on macrofungi of Phulchowki areas. 


\section{MATERIALS AND METHODS}

The collected specimens were illustrated based on the field study of fresh specimens and standard methods were followed for collection, preservation, morphological and microscopic studies (Atri et al. 2003). Morphological details such as shape, size, colour of the fresh specimens were recorded before preservation. For the identification chart of colours "the encyclopedia of fungi of Britain and Europe" authored by Michal Jordan (1995) was followed. Field photography was done using digital camera. Microscopic characterization was carried out with cotton blue lactophenol (1g/100 ml lactophenol). Crystals of 14 , dichlorobenzene were used to protect dried specimen from insect. Identification of various macrofungal genera was made using authentic publication of Adhikari (2000a), Arora (1996) and Singer (1986). Information related to species of various macrofungal genera was also taken from Hawkshworth et al. (1995) and Kirk et al. (2008). All the identified and unidentified specimens were deposited in Museum, Bacteriology and Natural Pesticide Laboratory, Department of Botany, DDU Gorakhpur University, Gorakhpur, Uttar Pradesh, India.

\section{RESULTS AND DISCUSSION}

During the survey 45 species of macrofungi were collected. Out of which 20 species were identified belonging to 13 families. These are individually described. The present description agrees with the description given by Jordan (1995).

Agaricus silvicola (Vitt.) Peck (FamilyAgaricaceae): Cap agaric with creamy white, pinkish or chocolate gills, stem with ring and bulbous base, Cap $6-10 \mathrm{~cm}$ dia, stem $4-8 \mathrm{~cm}$ tall $\times 1-1.5 \mathrm{~cm}$ dia, spores chocolate - brown, stem more or less equal with bulbous base, smooth, silky. Ring white.

Specimen examined - DDUNPL-077, On soil, Godavari, Altitude $1400 \mathrm{~m}$.
Date of collection: Aug. $28^{\text {th }}, 2010$.

Edibility - Edible

Amanita caesarea (Scop.: Fr.) Pers. (Family Amanitaceae): Hemispherical to flat, orange red, cuticle separable, gills free, yellow, Cap $6.0-2 \cdot 0$ $\mathrm{cm}$, stipe $8.0-13.0 \times 2.0-4.0 \mathrm{~cm}$ dia, narrow at the top, slightly swollen at the base, with large white membranous volva. Spore white elliptical, smooth.

Specimen examined - DDUNPL-078, On soil, Godavari, Altitude $1400 \mathrm{~m}$.

Date of collection: Aug. $25^{\text {th }}, 2010$.

Edibility - Edible

Bovista plumbea Pers.: Pers. (Family Agaricaceae): Small, white rounded structure attached to the substrate by mycelia threads, solitary or in scattered troops on soil in grasslands. Fruiting body $2.0-4.0 \mathrm{~cm}$ dia. $\times 1.5-4.0 \mathrm{~cm}$ tall. Gleba (spore mass) at first white and firm, becoming clay-brown. Spores brown, smooth, ellipsoid or sub-spherical.

Specimen examined - DDUNPL-079, on moist soil, near the army camp of Phulchowki,

Altitude - $1800 \mathrm{~m}$.

Date of collection: March $26^{\text {th }}, 2011$.

Edibility - Edible

Clavulina cristata (Holmsk.) Schroet (Family Clavulinaceae), Common name - crested coral fungus: Fruit body is like coral having numerous white branches, colour whitish but becomes cream with age. It grows $1.0-3.0 \mathrm{~cm}$ wide. Fruit body $2.0-8.0 \mathrm{~cm}$ in dia. base. Flesh white, spore deposit white.

Specimen examined - DDUNPL-080, On soil at the base of dead tree, Phulchowki,

Altitude $-1550 \mathrm{~m}$.

Date of collection: Nov. $17^{\text {th }}, 2010$.

Edibility - non-edible 
Clavulinopsis fusiformis (Sowerby) Corner. (Family - Clavariaceae): Bright yellow, small, slender, typically in dense tufts on soil in grasslands $0.4-0.6 \mathrm{~cm}$ dia. $\times 2.0-6.0 \mathrm{~cm}$ tall. Fruiting body, tips acute, no obvious distinction between fruiting body and stem, spore hyaline, smooth, sub-spherical with distinct apiculus, nonamyloid with droplets.

Specimen examined - DDUNPL-081, On soil in grassland near the water channel (moist place) or under the tree, Godavari, Altitude $1475 \mathrm{~m}$.

Date of collection: July $25^{\text {th }}, 2010$.

Edibility - non-edible

Clitocybe discolor Velen. (Family Tricholomataceae): Funnel-shaped cap, more pallid; at first convex, later infundibuliform, smooth with finely straight margin. Flesh white or grayish and thin. Gills whitish - grey, recurrent, spores hyaline, smooth, ellipsoid, non-amyloid, Basidia 4 - spored. Cystida absent. Stem concolorous with cap, smooth silky, more or less equal. Ring absent.

Specimen examined-DDUNPL-082, On log, Phulchowki, Altitude - 1675 m.

Date of collection: Oct $28^{\text {th }}, 2010$.

Edibility - non-edible

Coprinus disseminatus (Pers.: Fries) S.F.Gray (Family-Psathyrellaceae): Small, white, conical agaric with black gills, masses distinctively on stamp of broad - leaf and spreading to adjacent soil. Cap $0.5-1.6 \mathrm{~cm}$. Stem $1.5-3.5 \mathrm{~cm} \times 0.3-$ $0.6 \mathrm{~cm}$ dia. Gills white, stem white. Ring absent.

Specimen examined- DDUNPL-083, very large on stumps of trees, Godavari, Altitude 1440m.

Date of collection: Aug.19 $9^{\text {th }}, 2010$.

Edibility - non-edible
Coprinus lagopides Karst. (FamilyPsathyrellaceae): Talish, fragile, whitish then grey agaric covered with whitish scurf blackening; scattered on soil. Cap $2.5-5.0 \mathrm{~cm}$ tall $\times$ variable dia. Stem $2.0-1.0 \mathrm{~cm}$ tall $\times 0.2-1.0 \mathrm{~cm}$ dia. Cap grayish, surface covered with whitish - grey fibrils, Gills at first white, rapidly becoming dark, spores black, ellipsoid or sub-spherical. Stem white. Ring absent.

Specimen examined - DDUNPL-084, On humus containing soil, Godavari, Altitude $1450 \mathrm{~m}$.

Date of collection: Sep. 11 $1^{\text {th }}, 2010$.

Edibility - non-edible

Coprinus micaceus (Bull.) Fr. (Family Psathyrellaceae): Yellowish - tan agaric, eventually blackening; in dense clusters, on the stump of tree or on wood. Cap $1.5-3.0 \mathrm{~cm}$ tall $\times$ variable dia. Stem $3.0-8.0 \mathrm{~cm}$ tall $\times 0.4-0.8 \mathrm{~cm}$ dia. Cap yellowish-brown, becoming cinnamon towards the centre, bell- shaped and expanded-conical, gills brown and eventually black, spore dark-brown, sub-spherical. Stem white. Ring absent.

Specimen examined - DDUNPL085, on dead wood, Hatiban, Altitude $1380 \mathrm{~m}$.

Date of collection: Aug. $28^{\text {th }}$, 2011.

Edibility - Edible

Panaeolus sphinctrinus (Fr.) Quel. (FamilyBolbitiaceae): Small whitish agaric, drying paler, with mottled gills becoming black, in trooping groups on humus containing soil in grassland or on rotting straw. Cap $1.5-3.0 \mathrm{~cm}$ dia., Stem 5.0 $11 \cdot 0 \mathrm{~cm}$ tall $\times 0 \cdot 2-0 \cdot 4 \mathrm{~cm}$ diam, Cap white to grey. Gills darker grey and finally black, spores black, lemon-shaped, stem white, long, equal, slender. Ring absent.

Specimen examined - DDUNPL-086, on soil, Godavari, Altitude $1450 \mathrm{~m}$.

Date of collection: Oct.19 $9^{\text {th }}, 2010$.

Edibility - Non-edible 
Ganoderma applanatum (Pers.: Wallr.) Pat. (Family - Ganodermataceae): Very large graybrown bracket with knobbly appearance, underside pore-bearing whitish, parasitic on trunks of broadleaf trees. Fruiting body $8 \cdot 0-30 \mathrm{~cm}$ dia. $\times 3 \cdot 0-6 \cdot 0$ $\mathrm{cm}$ thick, grayish-brown, often discoloured reddish brown, dorsal surface whitish, spore more or less flattened, warty, ellipsoid.

Specimen examined- DDUNPL-087, On stump, Phulchowki, Altitude 2250m. Local name - Kathy chyau.

Date of collection: Aug. $27^{\text {th }}, 2010$.

Medicinal value

Ganoderma lucidum (Curtis.:Fr.) Karst. (Family Ganodermataceae): Large brown kidney - shaped bracket with lacquered appearance, underside spore - bearing, whitish, arising, from lateral stem, annual; solitary or in small groups, on stumps of broad leaf, favouring oak. Dimension $5-25 \mathrm{~cm}$ dia. $\times 2-4 \mathrm{~cm}$ thick. Fruiting body reddish brown, shiny, margin pallid when young, more or less flattened, radially wavy and concentrically groved and zoned, attached by stout lateral stem. Flesh cinnamon - brown, tough and fibrous. Pores white, bruising brown, becoming brown with age, Spores pallid brown, watery, broadly elliposoid, truncated at one end with hyaline germ pore, non - amyloid. Cystidia absent.

Specimen examined - DDUNPL-088 On wood debris of broad - leaf trees, Phulchowki, Altitude $1550 \mathrm{~m}$.

Date of collection: Aug. 28 $8^{\text {th }}, 2010$.

Medicinal value

Lycogala terrestre (L). Fr. (Family-Tubeferaceae): Small, spherical, puffball-like bodies, or orange, becoming palloid or gray at maturity, breaking down to reveal powdery pink spore mass, dead and rotten wood $1.0-3 \cdot 0 \mathrm{~cm}$ dia. Wall-study multiplelayered, outer surface containing vesicles filled with yellowish fluid, spores, sub spherical, covered with a fine network of thin ridges.

Specimen examined - DDUNPL-089, On dead wood, Phulchowki, Altitude $1550 \mathrm{~m}$.

Date of collection: Aug. $27^{\text {th }}, 2010$.

Edibility- Non-edible

Lycoperdon pyriforme Schaeff.:Pers. (Family Lycoperdaceae): Smallish dull brown or grey brown, pear shaped structure on a pedestal solitary or in troops on rotten wood or on soil. Fruiting body $2 \cdot 0-5 \cdot 0 \mathrm{~cm}$ dia. $\times 2 \cdot 0-4 \cdot 5 \mathrm{~cm}$ tall, gleba (spore mass) at first white and firm, becoming brown, spores olive-brown, smooth, spherical.

Specimen examined - DDUNPL-090, On rotten wood, Godavari, Altitude - $1500 \mathrm{~m}$.

Date of collection: June $25^{\text {th }}, 2010$.

Edibility - Edible

Macrolepiota excoriata (Schaeff. Fr) Wasser (Family-Agaricaceae): Large, flesh, agaric with pileus, gills and stipewithring, in scattered on soil. Cap 5.0-10cm dia, stem 3-5cm $\times 0.8-1.2 \mathrm{~cm}$ dia. Cap white with fine scales, at first bun-shaped, becoming expanded-convex and slightly umbonate, margin characteristically frayed, gills white free, spores hyaline, smooth, ellipsoid, stem white more or less equal but slightly swollen base. Ring present.

Specimen examined - DDUNPL-091, Among leaf litter of road side of Godavari, Altitude 1390m.

Date of collection:Aug. $27^{\text {th }}, 2010$

Edibility - Edible

Mycena phyllogena (Pers.) Sing. (Family Mycenaceae): Small, delicate, pale-brown, fleshcoloured agaric with conical cap, gills white and very long stipe, in small troops on litter or on stumps. Cap $1.0-3.0 \mathrm{~cm}$ tall dia., stem $4.5-9.0 \mathrm{~cm}$ $\times 0.2-0.3 \mathrm{~cm}$ dia., cap clay pink at tip, conical, stem brown, more or less equal. Ring absent.

ECOPRINT VOL 18, 2011 
Specimen examined - DDUNPL-092, Among leaf litter of road side of Godavari,

Altitude $1400 \mathrm{~m}$.

Date of collection: Aug25 ${ }^{\text {th }}, 2010$.

Edibility -Non-edible

Paxillus involutus (Batsch, Fr.) (Family Paxillaceae): Large agaric with brown, cap and stem, ochre brown gills, solitary or in trooping groups on soil, cap $5.0-12.0 \mathrm{~cm}$ dia. Stem 3.0 $5.0 \mathrm{~cm} . \times 0.5-1.0 \mathrm{~cm}$ dia. brown, at first convex, becoming expended and depressed but with persistently enrolled margin, downy especially at margin becoming smooth with age, also greasy at centre when damp flesh pallid ochraceous, thick, spore sienna-brown, smooth ellipsoid, nonamyloid, without droplets. Ring absent.

Specimen examined - DDUNPL-093, On soil and on dead trunk with forest, Phulchowki, Altitude $1500 \mathrm{~m}$.

Date of collection: Aug26 ${ }^{\text {th }}, 2010$.

Poisonous

Pleurotus cornucopiae (Paulet: Pers.) Rolland (Family - Pleurotaceae): Medium to large, cream, funnel-shaped cap or oyster-shaped cap, pale gills and short ecentric stem, on stumps, trunks and felled timber of broad-leaf trees. Cap $5.0-11.0 \mathrm{~cm}$ dia., stem $1.5-4.0 \mathrm{~cm}$ tall $\times 1.0-2.0 \mathrm{~cm}$ dia., cap wholly cream, oyster-shaped with some what wavy or lobed margin. Gills white, spores hyaline, smooth, ellipsoid or sub-cylindrical, non-amyloid, with droplets. Ring absent.

Specimen examined - DDUNPL-094, On litter or on stump, Phulchowki, Altitude $1550 \mathrm{~m}$.

Date of collection: March 26 ${ }^{\text {th }}, 2011$.

Edibility - Edible

Sparassis laminosa Fr. (Family-Sparassidiaceae): Large cauliflower like whitish, yellowish mass associated with wood, parasitic on soil. At the base $10-30 \mathrm{~cm}$ dia. Fruiting body pallid cream with buff ting, darking with age, short rooting stem, spore bearing surface ochraceous, spore spherical non-amyloid with droplets.

Specimen examined - DDUNPL-095, On soil, Phulchowki, Altitude $1800 \mathrm{~m}$.

Date of collection: Aug25 $5^{\text {th }}, 2010$.

Edibility - Edible

Volvariella speciosa (Fr.:Fr.) Kummer (Family Pluteaceae): Medium to large, agaric with whitish cap, the base of the stem encased in volvabag, solitary or scattered, on rotted straw, manured ground. Cap $4.5-7.0 \mathrm{~cm}$ dia., stem $6.0-10.0 \mathrm{~cm}$ tall $\times 0.8-1.6 \mathrm{~cm}$ dia., gills white, free, broad, crowded. Spore pink, smooth, ellipsoid, nonamyloid, stem white, smooth, tapering upwards, the base enclosed with volval sheath. Ring absent.

Specimen examined - DDUNPL-096, On soil, Phulchowki, Altitude 1800m.

Date of collection: March $28^{\text {th }}, 2011$.

Edibility - Edible

\section{ACKNOWLEDGEMENT}

Authors are thankful to the Head, Department of Botany, DDU Gorakhpur University, Gorakhpur for providing necessary lab facilities, and Prof. Kamal for his valuable suggestions. S.K. Jha thanks Tribhuvan University, Institute of Science and Technology for granting study leave.

\section{REFERENCES}

Adhikari, M.K. 2000a. Mushroom of Nepal. (ed.) G. Durrieu. P.U. Printers, Battisputali, Kathmandu, Nepal, pp. 236.

Adhikari, M.K. 2000b. A preliminary study on the mycodiversity of Maipokhari, East Nepal. Bull Natl. Sci. Mus. Tokyo, Ser. B26:67-74

Adhikari, M.K. 2001. New record of fleshy fungi from Kathmandu valley, Nepal-4. Green World 7:3-7. 
Adhikari, M.K. 2004. Mushroom poisoning and its state in Nepal Bull. Dept. Pl. Res. pp. 56-58.

Arora, D. 1996. Mushroom Demystified: A Comprehensive Guide to the Fleshy Fungi. Ten Speed Press, Berkeley, USA.

Atri, N.S. and H. Kaur. 2003.Wild Mushrooms Collection and identification. Mushroom Res. 14:56-59.

Chang, S.T. and P.G. Miles. 2004. Mushroom: Cultivation, Nutritional Value, Medicinal Effect and Environment Impact. Second edition. CRC Press, USA.

Christensen, M., S. Bhattarai, S. Devkota and H.O. Larsen. 2008. Collection and use of wild edible fungi in Nepal. Econ. Bot. 62(1):12-23.
Hawkshworth, D.L., P.K. Kirk, B.C. Sutton and D.N. Pegler. 1995. Ainsworth and Bisby's Dictionary of the Fungi. Int. Myco. Inst. CAB International, London, $616 \mathrm{pp}$.

Jordan, M. 1995. The Encyclopedia of Fungi of Britain and Europe. John Taylor Book Ventuse Ltd. (eds.) Devid and Charles, Brunel House, Newton Abbot, Devon, USA.

Kirk, P.M., P.F. Cannon, D.W. Minter and J.A. Stalpers. 2008. Ainsworth and Bisby's Dictionary of the Fungi $\left(10^{\text {th }}\right.$ ed). CAB International Walling Ford, U.K.

Singer, R. 1986. The Agaricales in Modern Taxonomy ( $4^{\text {th }}$ ed.) Seven koel, Scientific Books, D-62.40 Koenigstein, Germany. 